\title{
Réflexions pour 1985: a study in the vernacular of progressive compliance
} By Brian J. Sudlow

\begin{abstract}
:
Réflexions pour 1985, a prospective report published in 1964, envisaged what France might look like in 1985. This article argues that the blend of 'probable' and 'desirable' in its imagined vision of the future reveals an agenda of enforcing social compliance with its techno-scientific assumptions. To test such an assessment of the text, this article offers a study of the shaping factors and shaping actors of the report, before analysing the language of the report itself.
\end{abstract}

\section{Keywords:}

Réflexions pour 1985; Gaston Berger; Jean Fourastié; progress; ideology; technopolitics.

Réflexions pour 1985 was an extensive report published in 1964 by a special working party called the Groupe de 1985. The working party operated under the aegis of the Commissariat général du plan (CGP), France's central planning office established in January 1946 and first led by none other than French diplomat and economist Jean Monnet, one of the fathers of European unity. Réflexions sets out the working party's vision of what France would be like twenty years thence, tiptoeing discretely around any Orwellian allusions by adding a year to the final addition. It was an exercise in what the French call prospective, a formal and structured method of foresight. What was crucial to Pierre Massé, the haut commissaire of the CGP when Réflexions was published, was that such organized governmental foresight should simply as be seen as an exercise in anti-hasard (Massé, 1967). For Massé, an engineer by training, who had earned his spurs managing the French hydroelectric power stations of the postwar period, prospective was not dependent on the old myth of progress that predicted the evolution of the good things to come: it was simply a matter of judicious precaution in the face of existing or future risks. 
Whatever Massé's views, there is no doubt that prospective offers a formalization of the instinctive human need to envisage the future and prepare for it. Nowadays, on an international scale this need can be detected in the publication of the Global Risk Report every January (WEF, 2016). In this document experts from a whole series of natural and social sciences collaborate to produce a best-guess view of what the world's risks will be in the coming twelve months. In the realm of the imagination, this need for anticipation and preparation is seen in contemporary cinema's prolific reflection on the future. Even if futuristic cinema is often fraught with apocalyptic overtones - think of Elyseum (2013) or Mad Max: Fury Road (2015) - it offers, nevertheless, varied, powerful and creative attempts at decoding the future incarnations of present possibilities. Such films imaginatively write the positive and the negative narratives of the things that may yet be and risks yet to come.

Within France's domestic arena, reflection on the future was again revalorized by the 2013 relaunch of a French governmental office for prospective and future planning: the Commissariat général à la stratégie et à la prospective (CGSP). Planning as a discipline seemed to die a death in France after the fall of the Berlin Wall, its grave being marked paradoxically by a report (De Gaulle 1992) that advocated its reform and modernization. At the very least the schema of approximately quinquennial state planning that had pertained under all French governments since 1946 broke down, even if the CGP continued to fulfil various briefs at the request of the prime minister's office (Haut, 2002). While prospective as a discipline never went away, it was left to the French government's Centre d'analyse stratégique, founded in 2006, to bring the virtues of prospective back into political vogue, just in time to fail to see the coming crisis of 2007-8. Indeed, it was such failures that made the founding of the CGSP seem all the more necessary. At present, the CGSP is a tremendously active section of the prime minister's office, offering through France Stratégie, its web platform, a variety of reports and consultations on everything from the Internet of Things and the future of laïcité, to the France of 2025. As the Global Risk Report demonstrates, risk is the watchword of many institutions, and the CGSP is France's instrument for trying to forge responses to it.

In spite of the rational pretentions of prospective, however, is it really true that it has nothing to do with the myths of progress? Is prospective simply as anodyne as Pierre 
Massé described it - an anti-risk tactic, rather than an ideological tool? The very difficulty of separating foresight from ideologically wishful thinking is at the heart of this article's problematic. How individuals envisage their future is revelatory of their priorities, of their assumptions and of course of their hopes. How a State thinks about its future, on the other hand, is revelatory of how it understands the challenges of its own self-preservation. In this regard one of the most troublesome passages from Réflexions pour 1985 occurs in its "Foreword" where Pierre Massé offers the following thought:

The study in prospective which the working group was asked to undertake has highlighted various possibilities and led us to select a few future scenarios that will be informative but also useful as a basis for policy and action. These future scenarios that will guide our decisions are a blend of the probable (probable) and the desirable (souhaitable). Our task is less a matter of guessing haphazardly at the former, and more a matter of preparing the way for the latter (Groupe de 1985, 1964, 5).

The distinction made here between the probable and the souhaitable is itself very significant. Of course the probable might be seen as somehow scientific, insofar as one accords a kind of social scientific status to the discipline of prospective or foresight. It is precisely on this claim to a kind of scientific objectivity that prospective bases its authority (Godet, 2000). Yet what exactly constitutes the souhaitable (the desirable/ "wishable"), especially in a document that discusses not just constitutionally enshrined values - that we could at least understand - but a whole plethora of economic, social and even cultural values? There is, furthermore, another difficulty here. What is probable seems to depend on a concatenation of causes whose association are almost unavoidable: what is probable is probable for everyone in the path of those causes. What is souhaitable, on the other hand, evokes choices that reflect not necessity but option, inclination and preference. What then, we have to ask, are the implications of blending the souhaitable and the probable in a way that Massé obviously celebrates in such a document as Réflexions pour 1985 ?

In the search for an answer to that question, we must dig deeper into the history of the Réflexions pour 1985, studying important shaping factors of its genesis and notably 
the way in which the text is itself written. First, the timeframe of the document is significant. It was born more or less in the middle of De Gaulle's presidency that stretched from 1959 to 1969. It was a crucial moment in the political development of the Fifth Republic (founded in 1958) and the techno-optimism of Réflexions pour 1985 offers itself as a sign of the confidence of the period. Second, it is important to understand that the document was born when prospective was an evolving discipline. Réflexions pour 1985 was based solidly on theoretical perspectives that represented a critical response to the growing awareness of social acceleration (Halévy, 1947) and an incipient sense of the importance of technological forecasting (Quinn, 1967). Nevertheless, as this article will argue, at this stage in its history it was a theory with a potentially dangerous vacuum at its centre; one that could offer itself to any ideological manipulation according to the circumstances. The third task of this article will be to examine the human dimension of those circumstances, not least the key agendas of the Groupe de 1985's most influential member, Jean Fourastié. While many of his fellow group members were unknown outside of administrative circles, Fourastié stands out not only for his contributions to understanding post-war economic history - he was the forger of the expression "les Trente glorieuses" (the thirty years of economic growth from 1945-1974) - but also for his radically optimistic advocacy of the fruits of science and technology that have such a central role in Réflexions pour 1985. Fourastié's presence in the Groupe de 1985 provides a significant indicator of what the ideological vacuum in this prospective exercise risked attracting.

Having thus contextualized Réflexions pour 1985 and the problems of prospective, it will be essential finally to analyse the text itself, exploring the extent to which its formulations surpass what Massé acclaimed as a simple anti-risk exercise. In so doing, the aim will be to show not that the authors were wrong about the future; they were in various important ways correct. Rather, it will be to argue two things: first, that in spite of its social scientific pretensions, prospective as a tool of French governance in the mid-1960s, inflected by techno-scientific visions, was by no means free of the baggage associated with the myth of progress; and, second, that this baggage included, at least implicitly, an agenda of social compliance with the promises that progress offers. It is extraordinary that the lessons Colson and Cusset (2008, 150) draw from Réflexions pour 1985 concern only the technical difficulties of 
anticipating ruptures or trends, the report's interdisciplinary weaknesses or the problems of coherence. The danger of such documents practising surreptitious ideology under the cover of purportedly scientific forecasting, perhaps on the pretext that the spirit of prospective is more important than the method, goes unheeded. As this article will conclude, the unwitting ways in which such forces shaped the key messages of Réflexions pour 1985 ultimately provide the threads of a cautionary tale for today's institution of prospective, the CGSP.

\section{The historical moment}

The text of Réflexions pour 1985 was the fruit of twenty meetings held between January 1963 and February 1964, a timeframe implying a concerted not to say intense working rhythm. The aim of each session was to take a snapshot of future prospects and possible trajectories in a wide range of fields, including anthropology, education, transport, economics, science and technology, administration and agriculture. The regular team of discussants included not only Fourastié but that key figure of French future studies Bertrand de Jouvenel, better known for suing historian Zeev Sternhell (Sternhell 2012) for accusing him of fascism. The regular team of discussants, eleven in total, were joined for various sessions by other well-known experts, including anthropologist Claude Lévi-Strauss and leading intellectual and historian Raymond Aron. The 1985 Group was nothing if not a gathering of the grands hommes de la patrie.

The immediate consequences of the report were tangible. It helped shape the so-called 5th Plan, voted into law in November 1965 (Colson and Cusset 2008, 144), that marked a turning point between the four previous plans, all of which focused on postwar reconstruction, and the six plans to come that would aim substantially to promote France's economic growth. The report's call for the founding of prospective units across the administrative services was subsequently answered by the creation of such units in the ministries for Foreign Affairs, Defence and Industry. Beyond these realms of government, the document knew considerable success, especially for what was essentially a government report. It was translated into Japanese, though never into English, and in total over 100,000 copies were distributed. Whatever doubts one 
might entertain about the usefulness of foresight on such a long-term scale, the intense work of the varied and brilliant figures of the 1985 Group did not go to waste.

To take the context of Réflexions pour 1985 a little wider, the working party began its discussions in January 1963 at an interesting juncture rich in optimism, at least for some sections of French society. In his end of year speech for 1962, De Gaulle had spoken of progress as "our national ambition", promising to help the French take the next step on the road to economic and social development (Quoted in Viansson-Ponté 1971, 88). At the macro-economic level, the period 1958-1973 saw France's GDP rise by $123 \%$, a figure only exceeded by Japan (Adams 1989, 4). Five years into that period, the "plan de stabilisation" of 1963, published just before Réflexions pour 1985, marks the early stages of a process that saw French prospects prosper across a multitude of indices. The average French family benefited from a steady rise in the value of real wages and responded by increasing their consumption across a range of sectors (Mariano 1973). Serge Bernstein (Bernstein 1989) would call the 1960s a golden age for the salaried middle classes, even if such a rosy picture leaves aside social and regional inequalities, inflation and the fragility of overseas trade, not to mention the promise of troubles that would break out in May 1968.

Still, in January 1963 De Gaulle was surfing the crest of a wave of national support, manifested by the successful referendum of October 1962 in favour of universal suffrage for the presidential election. De Gaulle's momentum was boosted by victory in the legislative elections the following month when the presidential coalition captured 324 seats in the Assemblée, securing a majority of 172. Réflexions pour 1985 was thus published at a time when de Gaulle was safe, the monarchie républicaine (Duverger 1974) was enjoying a veritable heyday of political legitimacy, and the twilight of Gaullism was yet to begin (Bernstein 1989, 267).

Perhaps surprisingly, therefore, not all the report's preoccupations were prima facie recognisably Gaullist. Réflexions pour 1985 shows a keen awareness of the importance of developing regional powers and advancing regional reforms, a matter of administrative concern beginning with the reforms of 1963, but not really central to De Gaulle's vision of French grandeur. The report also evinces a concern for the kind of participatory democracy that smacks more of intensifying subsidiarity, rather than 
shoring up the populism signalled by De Gaulle's use of the plebiscite (Knapp and Wright, 2001, 55). Of course, we can suspect that the Gaullist dispensation, like all successful regimes, maintained its stability only through a skin-deep homogeneity. Behind this arguably lay a hybridity more suggestive of an implicit settlement between the strong men of Gaullist politics and the generation of French administrators whose work from the 1930s to the post-war period has been so convincingly rehearsed by Philip Nord (Nord 2012).

That said, Réflexions pour 1985 also echoes more recognisably Gaullist preoccupations. There is a discernible anti-Americanism right from the opening chapter (Groupe de 1985 1964, 12) where the USA is identified as a dangerous rival and leviathanic competitor (Kuisel 1993). The report also outlines a dazzling scientific and technological future for France, thereby inadvertently offering several hostages to fortune. The Concorde agreements had been signed only in November 1962 four days after the victory in the legislatives, so why shouldn't the 1985 Group have given their backing to Jean Bertin's doomed aérotrain that later lost out on its investment to the TGV? The report speaks of a civilisation nouvelle (Groupe de 1985 $1964,15)$ at the heart of which was a powerful drive for technological and scientific innovation - the kind of drive that inspired so many of de Gaulle's technological projects (Bernstein 1989, 237). In sum, the future technologies that the report tantalizingly evokes are like the avatars of hopeful optimism to which Réflexions pour 1985 gives voice. They are also Gaullist vectors for the next incarnation of what Robert Gilpin would later call the Scientific State (Gilpin 1968).

In a time coloured by Gaullist nostalgia for French power on the world stage, what was so very modern about Réflexions pour 1985 was that it represented an attempt to study that most intangible of scientific objects: things that have not yet come to pass. After the loss of its most important colonies, Réflexions pour 1985 stands perhaps as France's attempt to occupy, or at least lay a claim to, the country of the future (Lowenthal 1985). In this sense, the Réflexions pour 1985 belongs to its age not just because of its futuristic imaginings or optimistic predictions, but also by its method of supposedly penetrating the veil dividing the present from the future. Indeed, its methods were barely ten years old. 


\section{Réflexions pour 1985 as prospective}

The theory of prospective, the method on which Réflexions pour 1985 drew, had been elaborated during the mid-1950s by the late Gaston Berger. Berger, a philosophy graduate, businessman and civil servant, who died in a car accident in 1960, was to leave a scattered but rich body of reflections on prospective, its necessity, its methods and its goals. Alongside the work of Jacques de Bourbon-Busset and Pierre Massé, Berger's contribution to prospective would help pioneer a state technique aimed at taking France beyond the sclerotic strategies of planification and into a new era of rapid-response political action (Durance and Cordobes 2007).

Three key factors explained for Berger the need for prospective. The first was the ever-increasing power of science which by the end of the war had become great enough to destroy nature (Berger 2008 [1957a]). Humanity was becoming more powerful and this power needed something more adaptable than mere planification to control the consequences of its actions. This ever-increasing scientific power was, moreover, part of a wider phenomenon of social acceleration. In the shadow of Daniel Halévy's work on the acceleration of history, and anticipating Hartmut Rosa's (Rosa 2015) more recent theorizations of the subject, Berger wrote in 1957:

What is novel about the period in which we are living $[\ldots]$ is that acceleration has become immediately perceivable and affects us directly. It has now become a human measure: our contemporaries who are aged sixty have lived through three worlds while those who are thirty have lived through two. It took thousands of years $[\ldots]$ to match the speed of a gallop $[\ldots]$ but only fifty to break the sound barrier (Berger, 2008 [1957a], 58).

The last factor of note in the genesis of prospective is simply the contemplation of the consequences that arise from a lack of foresight (Berger 2008 [1956]). In the context of more powerful scientific resources and accelerating political, technological and social contexts, the prospect of government failing to anticipate the future turn of events becomes all the more alarming. Thus, for Berger, prospective was a necessity, 
offering not just a picture of humanity's future but a science of the "homme à venir" (the human to come) (Berger 2008 [1956]), 37).

So, what did this new science of prospective entail? Berger's thought on the matter is scattered throughout a series of articles and papers collected and republished by Philippe Durance in 2008. More recent theorisations of prospective, dating from the 1970s, engage with complicated methodologies based on the elaboration of scenarios (Godet and Durance 2011). Berger's method on the other hand was rehearsed in broader brush strokes that emphasized the multi-disciplinary business of what Berger simply called "prévisions" (forecasts) (Berger 2008 [1957a]). Whatever their disciplinary assumptions, Berger wanted philosophers to work with psychologists, sociologists, economists, teachers, engineers, doctors, statisticians and demographers, all towards one significant end that constituted a pragmatic balance of outcomes:

Too often have we had to bear the sight of wisdom separated from power. We must now wish to see working together those who can determine what is desirable and those who know what is possible (Berger 2008 [1957a], $61)$.

Arguably, whatever other purposes it serves, Massé's combination of the probable and souhaitable are an allusion to this very dilemma identified by Berger five years before the Groupe de 1985 was even founded. Prospective, to his mind, was not simply a passage between present and future but also a reconciliation of wisdom and power.

As high-minded as such ideals sound, two other features in Berger's prospective deserve closer attention, for they underline what is arguably its gravest weakness. The first is that Berger saw prospective as a philosophy of action to be realised through certain virtuous qualities (Berger 2008 [1957b]): what is possible can only be realised by those who are able. Thus, he advocates calm, imagination, team spirit, enthusiasm, courage and a sense of the human. Such a rehearsal of moral conditions is redolent of Berger's earlier work (Berger 1950) on character, inspired by Husserl. What is curious about these qualities, however, is that with the exception of the last, they are all about means, rather than about ends. They are in a word more about processes than 
they are about outcomes. Thus, while it is clear how Berger's version of prospective might speculate about the probable, it is far from clear how it can take any particular position with regard to the souhaitable.

The second thing to note - here reinforcing the tendency to the means-oriented qualities above - is that Berger comments often on the importance of ends over means yet rarely shows us what these ends ought to be (Berger 2008 [1958]). In fact, throughout his writings on prospective there seems to be a persistent eschewal of political ideals from either the left or the right that might otherwise indicate the value sources on which prospective is meant to draw. What emerges as a result is an ambitious and grandiloquent but vaguely colourless model of forecasting, without any way of measuring what goals have been forecast, or of determining what should be the focus of action. Even Berger's pretension to declare the desirability of an anthropologie prospective is undermined by the questions it begs about what future humanity should aim for and why.

This ideological vacuum creates an imbalance within prospective as developed by Berger, as well as raising questions about any document that purports to espouse Berger's methods. In the absence of tangible and discernible ends within the prospective method itself, any ends advocated on a prospective ticket as probable or souhaitable thus require even closer scrutiny. Furthermore, and in this very light, the contributors to the Groupe de 1985 - those determining just what is souhaitable become all the more interesting, not least the powerful and influential figure of Jean Fourastié.

\section{The hand of Fourastié}

The primacy of economic growth, driven by scientific and technological innovation, was one of the key theses about progress elaborated by Jean Fourastié in his 1949 study Le Grand Espoir du XXe siècle (Fourastié 1992). This Grand Espoir stood in sharp contrast with the Grande Peur du vingtième siècle (Mounier 1959) identified in a series of post-war lectures by Catholic intellectual Emmanuel Mounier who lambasted those who feared the effects of technological progress. Fourastié's thesis was illuminating: France's social progress had only come hitherto at the price of 
economic progress, and the same could only be true, he argued, for the future. Putting social progress before economic progress would thus be placing the cart before the horse. Moreover - and here was the techno-optimists' dream made theory - economic progress would only come at the price of scientific and technological development, and no technological progress was complete without improving the economy (Fourastié 1992, 80). Such, for Fourastié, was the lesson of the industrial revolution: only the innovations of industry could have broken the cycle of natural constraints to which pre-industrial society was subjected. At the same time, to counter the vices of that revolution, machinisme needed to reinvest human labour with the characteristics of autonomy and individuality that a thoughtless or rapacious mechanical culture $-\grave{a}$ l'Américaine of course - had supressed.

Well before the Groupe de 1985 was even thought of, such were Fourastié's convictions concerning France's technological future. A close reading of the report, however, shows that such agendas underscore much of the thinking in Réflexions pour 1985. The importance of economic growth takes centre stage (Groupe de 1985 1964, 45-50). At the same time, the report in its longest chapter (Groupe de 1985 1964, 113 123) simply drools over the possibilities and benefits of technological progress, inspired by the rapid rhythm of innovation since the end of the war in the fields of transport, arms, energy, electronics and communication technologies. The report predicts with confidence the emergence of consumer technology markets and comes finally to that most techno-optimist, indeed Fourastian, of conclusions: there are no technological problems, only human problems.

Alongside these preoccupations is the other Fourastian trope, mentioned above, of retaining the human dimension in the midst of technologized culture. It was a preoccupation that Fourastié shared in fact with Gaston Berger, although the former started from a position of Christian humanism, while the latter was a phenomenologist. Aesthetics and leisure are accorded two chapters in the report and the fact the first chapter is devoted to l'homme de 1985 suggests strongly that however the report views economic progress and its technological drivers, it envisages no progress that simply ignores the needs of the human. Berger would have been proud; Fourastié surely must have been. 
Paradoxically, Fourastié would lose his confidence in the pretensions of prospective not long after the end of the Trente Glorieuses. In a joint study published in the 1980s, Fourastié and his economist daughter Jacqueline would argue that latetwentieth century science was marked by an engagement with the implications of imprévisibilité, and a recognition of the importance of events or effects in nature that are rare, unique, unrepeatable and necessarily unforeseeable (Fourastié and Fourastié 1987, 186). Perhaps more importantly, in the 1992 re-edition of Le Grand Espoir $d u$ XXe siècle, Fourastié is much more circumspect about modelling the future than in the first edition of 1949. Indeed, in the "Postface" he states quite baldly: "Now, the future seems to me mostly unforeseeable" (Fourastié 1992, 391). He comes to this conclusion on the basis that the picture in 1992 is much more complicated than it was in 1949 when economic factors were predominant. By 1992, he also argues, the factors of change had not only become more complex but also more accelerated.

We are not of course obliged to accept this logic; as mentioned above, Halévy reflected on social acceleration after the war, and it was one of the very reasons Berger developed prospective in the first place. The Fourastié of 1992 was an older and slower figure and one certainly less invested in State building than he had been in 1949. He had also seen both the realisation of certain hopes and the evaporation of others. Nothing should surprise us less in fact than that the young Fourastié felt he knew the future while the old Fourastié felt he could not know it at all.

In any case, what is clear is that the younger Fourastié's convictions about technology and humanity are embraced by Réflexions pour 1985. When this fact is juxtaposed with the ideological vacuum of prospective, we can justifiably conclude that the embrace of Fourastié's vision of economic progress, driven by an ever-advancing techno-scientific mastery of reality, is a signal of the way in which the report's authors intended to define the souhaitable. A textual analysis of the report will only make this conclusion clearer.

\section{Réflexions pour 1985: a text analysis}

The preceding sections of this article have provided an assessment of the shaping factors and shaping actors that help us to decipher the mixing of the probable and the 
souhaitable in the Réflexions pour 1985 that Pierre Massé proclaims with such relish. The aim of this final section is to enter into the detail of the report's text in order to test how this blend is achieved. The hypothesis here is that the report acts through an affirmation of the inevitable and the complex, two categories of phenomena that the report's readers are supposed to find themselves powerless to resist. Indeed, it is the powerlessness of the reader encouraged by this language that offers proof of the document's desire for compliance with the vision that it offers.

The approach adopted here echoes that taken by Pierre Bourdieu and Luc Boltanski in their 1976 article 'La production de l'idéologie dominante' (Bourdieu and Boltanksi 1976). Therein they establish the typical vernacular of the French social philosophy on which so many official documents of the period were dependent. In the case of Réflexions pour 1985 - a text that appears not to have figured in their corpus - the frequency of certain terms and expressions provide what we can take as the foundation for a vernacular of prospective aimed at inducing compliance with the standards of techno-scientific progress. Now, in this regard, the two terms that appear to give greatest expression to the probable and the souhaitable are technique and civilisation.

"Technique" is simply everywhere in Réflexions pour 1985, both as a noun and as an adjective. That said, certain of its collocations seem to predominate. The expression les techniques nouvelles (Groupe de 1985 1964, 10, 125, 131) provides useful service, as does the rather Gaullist la technique française (Groupe de 1985 1964, 14). Taking technique as an adjective, we find recherches techniques, aspects techniques and the honourable progrès techniques (attested ten times). Technique appears, therefore, as the epithet of the hour, enjoying a role that is both conceptual and linguistic. Its rhetorical force, however, lies in its inevitability. The report is quite clear: France's only chance of survival is to place the imprint of French technology on the international phenomenon of technological evolution. If anything is probable, it is the inevitable importance not to say dominance of la technique. The only choices to be made by the reader, who must be otherwise docile before their techno-scientific destiny, concerns how technique is to be deployed or exploited. 
Then comes the shift towards the souhaitable, expressed in the use of the word civilisation. If technique is the means, civilisation (attested 23 times in the report) is the end. It appears in a variety of guises. At one point it is la civilisation nouvelle (Groupe de 1985 1964, 15) and la civilisation moderne (Groupe de 1985 1964, 16). The authors already lay claim to the future by referring to the civilisation de 1985 (Groupe de 1985 1964, 37). This civilisation has many characteristics expressed at various moments in the text: it is la civilisation des loisirs (Groupe de 1985 1964, 82) and then again la civilisation audio-visuelle (Groupe de 1985 1964, 84). In case any readers are feeling alienated from this civilisation, it is also characterized as an irresistible civilisation collective (Groupe de 1985 1964, 83).

Alongside the inevitability of this collective civilisation, its outstanding feature appears to be its complexity, a quality that offers itself against the deconstruction its critics would wish it to be subjected to. It is shaped by technological forces and driven by national agendas; at the same time, it cannot be bounded by national borders, and the report is quite clear about the coming Europeanization (Europe is mentioned 34 times) and burgeoning globalization of French affairs. The text defuses resistance to all these forces by insisting on the bamboozling nature of a complex future. It is not that the future is so bright we have to wear shades; it is rather that it is so complicated we need our technocrats.

To return to the problem of the probable and souhaitable, from the report's perspective the souhaitabilité of this civilisation seems wrapped up precisely in its complexity, a characteristic which in itself makes the new civilisation irresistible or inevitable. The report's forecasts for the future are desirable not only by being the latest thing - an old trope of progressive mythology: the snobbery of the present - but by being something so utterly complex and totally transformative that they must be yielded to. What else is a civilisation shift if not totally transformative? For the Réflexions, the world of 1985 is not just a new France; it is a new civilisation. A change in government might change your tax burden. A change in civilisation, however, would change your entire life.

Pierre Massé's blithe amalgamation of probable and souhaitable - echoing of course Gaston Berger - now takes on a new meaning, forcing on the reader the civilizational 
redirection that is only souhaitable by the report's own standards. To use the terms of Katarina Reiss's text type theory (Reiss 1971), Réflexions pour 1985 sets out to be informative, offering a forecast of the mid-1980s as a source of reflection and public action. Yet, in point of fact, the report is also unquestionably appellative, bidding, not to say obliging, its readers to embrace the future that it outlines. At least in the light of the report's own vernacular, Réflexions pour 1985 aims not only to imagine the future but also to construct it framework and drill its compliant participants.

\section{Conclusion}

The progressive error that constitutes Réflexions pour 1985 is one that has been laid bare by Paul Virilio in his L'Accident originel (Virilio 2005). Celebrating innovation is all very well, says Virilio, but one must never forget: the invention of any technology is the invention of its accidents. The invention of the train is the invention of the derailment. The invention of the computer is the invention of the software virus. The gaping hole in Réflexions pour 1985, in its forceful blending of the probable and the souhaitable, surely lies in the unwitting accidents of the technique of perspective. As a result of these very accidents whose risks remained unimagined, the report does not even begin to conceptualize what the accidents of this technological civilisation might be, let alone allow for the possibility that what it proposes may not in fact be what others desire. Contrariwise, it is only in being free to imagine what the accidents of a technological civilisation could be that one might freely choose to embrace such a future or imagine another.

\section{References:}

Adams, William James. 1989. Restructuring the French Economy: Government and the rise of competition since World War II. Washington DC: The Brookings Institute.

Berger, Gaston. 1950. Traité pratique d'analyse du caractère. Paris: PUF. 
Berger, G. 2008 [1956]. "Le problème des choix: facteurs politiques et facteurs techniques “, De la prospective: textes fondamentaux de la prospective française. Paris: L’Harmattan, 43-54.

Berger, G. 2008 [1957a]. “Sciences humaines et prévision”, De la prospective: textes fondamentaux de la prospective française. Paris: L'Harmattan, 55-64.

Berger, G. 2008 [1957b]. "L'accélération de l'histoire et ses conséquences”, De la prospective: textes fondamentaux de la prospective française. Paris: L'Harmattan, 6574.

Berger, Gaston. 2008 [1958]. "Humanisme et technique", De la prospective: textes fondamentaux de la prospective française. Paris: L'Harmattan, 83-86.

Bernstein, Serge. 1989. La France de l'expansion: la République gaullienne 19581969. Paris: Seuil.

Bourdieu, Pierre and Luc Boltanski. 1976. “La production de l'idéologie dominante”, Actes de la recherche en sciences sociales, 2:2, 3-73.

Colson, Aurélien and Yves Cusset. 2008. "Retour sur un exercice de prospective: Réflexions pour 1985", Horizons stratégiques, 1:7, 142-150.

De Gaulle, Jean. 1992. L'avenir du plan et la place de la planification dans la société française. Paris: La Documentation française.

http://temis.documentation.developpementdurable.gouv.fr/documents/temis/9836/9836.pdf Accessed 2 February 2016.

Durance, Philippe and Stéphane Cordobes. 2007. Attitudes perspectives: éléments d'une histoire de la prospective en France après 1945. Paris: L'Harmattan.

Duverger, Maurice, 1974. La monarchie républicaine ou comment les démocraties se donnent des rois. Paris: Robert Laffont. 
Fourastié, Jacquéline and Jean Fourastié. 1987. D’une France à une autre: avant et après les trente glorieuses. Paris: Fayard.

Fourastié, Jean. 1992 [1949]. Le Grand Espoir du XXe siècle. Paris: Gallimard.

Gilpin, Robert. 1968. France in the Age of the Scientific State. Princeton, N.J.

Princeton University Press.

Godet, Michel. 2000. "La prospective en quête de rigueur: portée et limites des méthodes formalisées", Futuribles, 249, January. Accessible at:

http://www.laprospective.fr/dyn/francais/articles/articles/quete_de_rigueur.pdf Accessed: 5 February 2016.

Godet, Michel and Philippe Durance. 2011. La prospective stratégique - 2e édition Pour les entreprises et les territoires. Paris: Dunod.

Groupe de 1985. 1964. Réflexions pour 1985. Paris: La Documentation française.

Halévy, Daniel. 1947. L'essai sur l'accélération de l'histoire. Paris: Fayard.

Haut, Claude. 2002. Rapport législative. Available at:

http://www.senat.fr/rap/np01_37/np01_37_mono.html Accessed 2 February 2016.

Knapp, Andrew and Vincent Wright. 2001. Government and Politics of France.

London: Routledge.

Kuisel, Richard F. 1993. Seducing the French: The Dilemma of Americanization.

Berkeley: University of California Press.

Lowenthal, David. 1985. The Past is a Foreign Country. Cambridge: Cambridge University Press.

Mariano, Antoine-Pierre. 1973. Métamorphose de l'économie française 63-73. Paris: Arthaud. 
Massé, Pierre. 1967. Le plan ou l'anti-hasard. Paris: Gallimard.

Mounier, Emmanuel. 1959. Grande Peur du vingtième siècle. Paris: Seuil.

Nord, Philip. 2012. France's New Deal: From the Thirties to the Post-war Era.

Princeton: Princeton University Press.

Quinn, James Brian. 1967. 'Technological forecasting', Harvard Business Review. 45:2, Mar-Apr, 89-106.

Reiss, Katarina. 1971. Possibilities and Limitations of Translation Criticism. Categories and Criteria for a Fair Evaluation of Translations. Munich: Hueber.

Rosa, Hartmut. 2015. Social Acceleration: A New Theory of Modernity. New York: Columbia University Press.

Sternhell, Zeev. 2012 [1983]. Ni droite ni gauche: l'idéologie fasciste en France. Paris: Folio.

Viannson-Ponté, Pierre. 1971. Histoire de la République gaullienne: le temps des orphélins. Paris: Fayard.

Virilio, Paul. 2005. L'Accident original. Paris: Galilée.

WEF. 2016. Global Risks Report, $11^{\text {th }}$ Edition (World Economic Forum). http://www3.weforum.org/docs/GRR/WEF_GRR16.pdf Accessed 21 January 2016. 